Valentina HLEBEC, Srna MANDIČ*

\title{
SOCIALNE INOVACIJE KOT NOV TIP KOLEKTIVNEGA DELOVANJA**
}

Povzetek. Socialna inovacija (SI) je sodoben pojav, katerega značilnost je prizadevanje za neko izboljšavo na področju blaginje, in to z vzpostavitvijo novih povezav med akterji iz različnih sektorjev. Cilj člankka je na podlagi obsežne in raznovrstne literature poiskati nastavke $z a$ razumevanje SI $v$ dveh teorijah. Pokažemo, kako je po strukturacijski teoriji SI možno konceptualizirati kot obliko kolektivnega delovanja, po teoriji kompleksnosti pa kot obliko samoorganizacije. Nadalje izpostavimo dva mehanizma, ki sta po obeh teorijah pomembna za vznik in obstoj kolektivnega delovanja in - kot pokažemo - celo konstitutivnega pomena ob soočanju stveganji in ovirami, ki so specifične za SI. Prvi je skupno učenje in pridobivanje znanja, vitalno pomemben za ohranjanje kohezivnosti akterjev ob srečevanju z novim in neznanim. Drugi je decentralizirano vodenje, ki s specifičnimi veščinami omogoči premoščati razlike $v$ znanju, načinu dela in organizacijski kulturi med različnimi akterji. Pomen teh mehanizmov in vlogo javnega sektorja pokažemo na dveh primerih SI: skupnost prakse" in "živi laboratorij».

Ključni pojmi: socialne inovacije, samoorganizacija, kolektivno delovanje, strukturacijska teorija, teorija kompleksnosti, decentralizirano vodenje

\section{Uvod}

Pri premišljevanju o ključnih razvojnih vprašanjih imajo inovacije v sodobnih družbah nesporno pomembno vlogo. Tako je tudi v Sloveniji, a $s$ to posebnostjo, da se omenjajo skoraj izključno le v smislu gospodarskih, tehnoloških in okoljskih inovacij, socialne inovacije pa praktično ne. $\mathrm{V}$ politikah EU pa imajo socialne inovacije (v nadaljevanju SI) pomembno vlogo (glej Pisano et al., 2015; Hubert, 2010; Barroso 2011), opredeljene so kot

* Dr. Valentina Hlebec, redna profesorica, Fakulteta za družbene vede, Univerza $v$ Ljubljani, Slovenija; dr. Srna Mandič, znanstvena svetnica, predstojnica Centra za proučevanje družbene blaginje, Fakulteta za družbene vede, Univerza v Ljubljani, Slovenija.

** Izvirni znanstveni članek. DOI: 10.51936/tip.58.1.5-27 
inovacije, ki so socialne po rezultatih in po svojih sredstvih ... So nove ideje (proizvodi, storitve in modeli), ki hkrati zadovoljujejo neko družbeno potrebo (učinkoviteje od alternative) ter ustvarjajo nove družbene povezave ali sodelovanje. (Bureau of European Policy Advisers, 2010: 9)

Tudi OECD (2011) pripoznava njihov pomen in značilnost, da v razvoj blaginje vnašajo nove proizvode/storitve in nove načine njihove proizvodnje in upravljanja, s poudarjeno vlogo ljudi samih in njihovega opolnomočanja. Pojav SI je tema, za katero je vse več zanimanja tudi v družboslovju, od množice objav do velikih raziskovalnih projektov v okviru EU-programa Obzorje 2020, kjer je bil poudarek prav na inovacijah (glej Bežovan et al., 2016).

Pojav SI se v zadnjem desetletju kaže kot val iniciativ, ki jih poganjajo civilna družba, socialna in druga podjetja, lokalne skupnosti in vlade ter ki želijo nasloviti nezadovoljene družbene potrebe na inovativen način (Oosterlynck et al., 2013). V njih nastajajo novi tipi povezav med družbenimi akterji iz javnega, tržnega, civilnodružbenega in neformalnega sektorja, z oblikami državljanske participacije, samoorganizacije lokalnih skupin, različnih tipov sodelovanja lokalnih skupnosti in države, podjetij. Prihaja do novega načina mešanja in kombiniranja različnih virov - npr. EU, lokalnih skupnosti, društev, države, družbenoodgovornih podjetij, prostovoljnega dela itd. Prav vzpostavljanje novih povezav med temi sektorji velja za enega ključnih razpoznavnih znakov SI.

SI vznikajo kot odgovor na različne probleme na področju blaginje in v širokem problemskem spektru ter hočejo zapolniti vrzeli v oskrbi s storitvami v nekem okolju in/ali za prikrajšane oz. izključene skupine, pogosto ob problemih različnih oblik prikrajšanosti (Brandsen et al., 2016; Evers et al., 2014; Evers in Ewert, 2015; Moulaert et al., 2013; Mulgan et al., 2007; Mulgan, 2015; Nicholls et al., 2015; van der Have in Rubalcaba, 2016). Jane Jenson (2015) jih razume kot nove oblike angažiranja, opolnomočanja in politične mobilizacije, ki naslavljajo številne neoptimalne konfiguracije družbenih odnosov in predstavljajo protiutež neoliberalnim pogledom na blaginjo. Tipično se SI umeščajo v okvir vključujočega socialnega in prostorskega razvoja. SI nastajajo $\mathrm{v}$ različnih pojavnih oblikah in $\mathrm{z}$ raznoterimi zastavki, med bolj pogostne tipe sodijo socialna podjetja, participativno in skupnostno usmerjene prenove urbanih področij in sosesk ter podporne storitve in centri za družine (Brandsen et al., 2016; Evers et al., 2014). V okviru boja proti revščini obravnavajo SI kot prakse, akcije in politike, ki omogočajo družbeno izključenim in obubožanim prebivalcem in družbenim skupinam zadovoljiti osnovne potrebe, za kar ne najdejo primernih rešitev na trgu ali v institucionaliziranih blaginjskih politikah (Evers et al., 2014). V Sloveniji so najbolj znani primeri SI socialna podjetja in časovne 
banke (Crnkovič, 2009), naključen širši nabor primerov pa obsega od prostovoljske ponudbe prevoza starejšim Prostofer do izposoje gospodinjskih predmetov Knjižnica reči (glej Hlebec in Filipovič Hrast, 2020). Kot pojav so SI obravnavali na ožjih področjih, predvsem v socialnem delu (Vujovič, 2015; Žiberna, 2017) ter v grajenem okolju (Sendi, 2014).

K pojavljanju SI je vodilo več zgodovinskih okoliščin, v katerih se je izražal kritičen odnos do birokratiziranosti in centraliziranosti države blaginje (glej Evers, 2005; Evers in Ewert, 2015; Oosterlynck et al., 2013; Mulgan, 2015). Najprej, SI so dediščina družbenih gibanj iz šestdesetih in sedemdesetih let, ki so se rigidnim centraliziranim ustanovam države blaginje zoperstavljala $z$ idejami večje participacije in krepitve moči »od spodaj« (empowerment), samo-organizacije in angažiranja ob družbenih problemih. Nadaljnja spodbuda za nastanek SI je bil odpor do standardiziranosti in uniformiranosti storitev povojne države blaginje, ki je s svojim centraliziranim in hierarhičnim upravljanjem teh storitev sicer zagotavljala enakost $\mathrm{v}$ dostopu do njih, ni pa dopuščala dovolj možnosti za lokalne specifike in za iniciativo od spodaj. Med dejavniki, ki so vplivali na pojav SI, so bile tudi neoliberalne politike s svojimi menedžerskimi pristopi, usmerjenimi $\mathrm{k}$ racionalizaciji porabe javnega sektorja. Za razliko od podpornikov neoliberalizma, ki so v samopomoči in državljanski participaciji videli pozitivno vlogo SI kot nadomestka in opravičila za krčenje javnih storitev, pa ključni avtorji izpostavljajo prav specifično dopolnilno vlogo SI (Evers in Ewert, 2015; Mandič in Hlebec, 2020). Inovacije v obliki samopomoči in participacije niso nadomestilo za dostopnost javnih storitev, ampak njihovo dopolnilo (Berner in Benedict, 2005).

$\mathrm{Na}$ tem idejnem ozadju se je odpiral prostor za nastajanje SI kot novega načina delovanja s poudarkom na avtonomiji, skupnostnem delovanju ter iniciativnosti in participaciji civilne družbe. Ob omenjenih težnjah so se spreminjali tudi sistemi blaginje z večjo pluralizacijo in pripoznavanjem vloge različnih sektorjev (nevladnega, komercialnega, prostovoljskega, neformalnega) v zagotavljanju blaginje, $\mathrm{v}$ »blaginjski mešanici« (welfare mix), ki predstavlja mrežo različnih producentov blaginje. Prav tako se je spreminjal način vodenja javnih politik na področju blaginje; postal je bolj vključujoč, sodelovalen in dialoški ter manj hierarhičen in osrediščen v državi. Vse to predstavlja zgodovinskorazvojni kontekst (pregledno o tem v Mandič in Hlebec, v tisku), v katerem se danes pojavljajo SI s svojim specifičnim mestom $v$ reorganizirani blaginjski mešanici in ob bolj vključujočem načinu vodenja.

Za razliko od zgodovinskorazvojnega vidika SI pa v tem članku pozornost namenjamo njihovi specifični praksi. Natančneje, zanima nas proces, kako SI v nekem okolju vznikne in se razvija. Ob pregledu obsežne in raznovrstne literature bi radi ugotovili, kateri so ključni dejavniki v tem procesu 
in kako jih razumeti. Zato si zastavljamo naslednja raziskovalna vprašanja. Najprej želimo ugotoviti, kakšne so značilnosti in posebnosti SI v primerjavi tržnimi inovacijami in tistimi, ki so na področju blaginje sprožene sistemsko, saj te značilnosti vplivajo tudi na različno dinamiko inovacij. Nadalje, iščemo in preverjamo nastavke za razumevanje specifike SI v dveh aktualnih teorijah - strukturacijski teoriji in teoriji kompleksnosti. Osrednji cilj člankka pa je identificirati in podrobneje razčleniti dejavnike, ki so za družbeno inovacijo kot obliko kolektivnega delovanja konstitutivnega pomena, ter to njeno vlogo ponazoriti s konkretnimi primeri.

\section{Posebnosti SI v primerjavi z drugimi inovacijami}

Številni avtorji opozarjajo na nevarnost, da bi SI preveč enačili z idejami in pojmovanji, ki za inovacije veljajo v tržnem in javnem sektorju. Medtem ko splošno privzeti model življenjskega cikla inovacije predvideva, da se inovacija pojavi in potem nujno tudi razširja in deli naprej (diseminacija), pa je empirična raziskava WILCO (Brandsen et al., 2016) pokazala nekaj drugega. V analiziranih primerih SI med akterji namreč niso zasledili želje po rasti in razširjanju; nasprotno, pogosto so izpričevali enkratnost, neponovlji-

8 vost in lokalno vraščenost $\mathrm{v}$ konkretno okolje.

Če je ključna značilnost SI to, da so to inovacije v družbenih odnosih in v zadovoljevanju človekovih potreb (Moulaert, 2016), se postavlja vprašanje, $\mathrm{v}$ čem so posebne $\mathrm{v}$ primerjavi z drugimi inovacijami, ki so tudi prisotne in vplivne na področju človekove blaginje - na eni strani tržne inovacije in na drugi strani z javnimi politikami sprožene sistemske inovacije. V nadaljevanju izpostavljamo nekaj pomembnih točk razlikovanja med njimi.

Tradicionalni pogled na inovacije je osredotočen na razvoj inovacij na trgu; inovacija je tu razumljena kot nova ideja, ki jo usvoji podjetnik, ki ve, kako jo "prevesti« $\mathrm{v}$ inovativen proizvod za trženje; popularizacija z oglaševanjem je normalna strategija trženja. Inovacija in njeno razširjanje sta torej imanentna dela tržne iniciative in prizadevanja za dobičkom. V primerjavi s tržnimi inovacijami pa so motivi SI izboljševanje blaginje, vključevanje skupin, demokratizacija politik in aktivnosti civilne družbe. Motivi so pogosto povezani in prepleteni, tako da se podjetna logika lahko poveže z idejami, ki vzniknejo v lokalnih sistemih blaginje, iz gibanj in iz tretjega sektorja. Pomembna razlika je tudi, da med tržnimi inovacijami absolutno prevladujejo proizvodi, v SI pa storitve. Zato se SI bolj navezujejo na trajnejše odnose, ne pa toliko na enkratne transakcije, ki so značilne za trg. Zato so SI bolj odvisne od specifičnih družbenih razmerij in družbenega konteksta kot tržne inovacije.

Za tržne inovacije in njihovo razširjanje je relevantno in dokaj dobro raziskano vprašanje, kaj jih napravi bolj sprejemljive. Rogers (2003) je z 
empirično študijo identificiral naslednje dejavnike, ki vplivajo na hitrost in obseg sprejemanja in razširjanja inovacij med ljudmi: zaznana prednost nove rešitve pred staro (je npr. cenejša, prikladnejša, prinaša ugled itd.); skladnost $z$ vrednotami in prejšnjimi izkušnjami uporabnika; enostavnost in lahkost uporabe (razumljivost, učenje ni potrebno); možnost predhodnega preizkusa (manjše tveganje); vidnost rezultatov. Slednja dejavnika zadevata to, kako posamezniki dojemajo tveganja, ki spremljajo novost. To, da se ljudje pri takih odločitvah zanesejo na informacije, ki jih dobijo od zaupanja vrednih znancev, uporabljajo tudi v sodobnih oblikah trženja. Tako kampanje usmerjajo na omrežja znancev in kolegov ter poskušajo rekrutirati izpostavljene člane, da znotraj teh omrežij predstavljajo in razširjajo nove ideje (npr. pripomočke za različne gospodinjske prakse). Zaupanje in skupinska pripadnost, na katere računa ta oblika sodobnega trženja, pa imata pomembno vlogo tudi $v$ SI.

SI imajo nekaj podobnosti in ključnih razlik tudi $v$ primerjavi $z$ inovacijami, ki jih na področju blaginje sprožajo javne politike in spremembe v delovanju sistemov. Večje sistemske spremembe, npr. reforme, so tipično sprožene in vpeljane oz. implementirane od zgoraj navzdol, medtem ko imajo SI močno noto samoorganizacije. Nadalje, kot poudarjata Hallie Preskill in Tanya Beer (2012), imajo SI različen pristop, kot je implementacija preizkušenega in stabilnega programa $v$ javnem sektorju. SI vključuje proces samega nastanka ideje, preizkušanja in izpeljave rešitve. Pot do cilja je pri SI manj jasna, poti do rezultatov in časovni okvir pa so manj predvidljivi kot $\mathrm{v}$ primeru implementacije preizkušenih programov. SI ne morejo vnaprej z gotovostjo predvideti rezultatov, saj med akterji in v okolju sprožajo spremembe, ki so enkratne ter posebne za ta čas in prostor. Zato je SI eksploratoren proces, ki je bolj negotov od tradicionalnih oblik sistemske intervencije. Zahteva tudi poseben tip evalvacije, ki vključuje strateško učenje kot sestavni del razvoja inovacije.

Drugače kot pri tržnih in politično induciranih sistemskih inovacijah pa je za SI značilno, da se pojavijo kot kontekstualno vpeta reakcija ljudi na skupno izkušnjo vsakdanjega življenja, izkušnjo neuresničenih potreb ali skupnih težav, ki jih srečujejo v obstoječih institucionalnih postopkih (Chambon et al., 1982). Za razumevanje tega, kako SI vzniknejo in se razvijajo, je nujno upoštevati prav to skupno izkušnjo ljudi kot osnovo za delovanje v konkretnem okolju (Moulaert, 2010). Ob prostorski bližini pa se ljudje tudi hitreje soočijo s skupno težavo in mobilizirajo vire za spopad z njo; velja, da v vsakodnevnem življenjskem okolju lahko civilna družba, podjetniki in lokalne javne ustanove hitreje in lažje pridejo do rešitev. 


\section{SI kot kolektivno delovanje: med strukturacijsko teorijo in teorijo kompleksnosti}

SI implicirajo prakso, aktivnost, delovanje. SI so kolektivne iniciative za zadovoljitev specifičnih potreb, so "princip, ki strukturira kolektivno akcijo" (Moulaert, 2016: 13). Da bi ta pojav razumeli v širši teoretski perspektivi, ga lahko umestimo v razmerje med strukturo in človekovo delovanje (structure/agency). Družbena struktura in človekovo delovanje lahko nastopata kot predmet medsebojno izključujočih se pristopov, pri čemer prvi, objektivistični pristop poudarja strukturne danosti, ki določajo objektivno dane možnosti človekovega delovanja, drugi, subjektivistični pa izpostavlja odločilno vlogo volje in subjektivnih zmožnosti človekovega delovanja. V novejšem času se vse bolj uveljavljajo pristopi, ki strukturo in delovanje razumejo kot soodvisna in vzajemno delujoča, začenši s strukturacijsko teorijo (Giddens, 1981) in njeno aplikacijo na različna področja (Moos in Dear, 1986; Mandič in Filipovič Hrast, 2018; Moulaert et al., 2016). Družbene strukture postavljajo pravila in vire človekovemu delovanju, torej ga omejujejo in tudi podpirajo; te strukture pojasnijo, zakaj v prostoru in času pride do istih oz. podobnih praks, medtem ko človekovo delovanje razloži, zakaj so v

10 istem okolju, ob istih strukturnih pogojih, prakse lahko tako različne.

Če ta pristop uporabimo na primeru SI, potem nam strukturacijska teorija pokaže na eni strani obstoj strukturnih okoliščin, npr. neodzivnost neke sektorske politike na nov problem, ter na drugi strani odgovor na to - delovanje, npr. ustanovitev društva za samopomoč. Pri tem je od strukturnih okoliščin spet odvisno tudi, na kakšne pogoje delovanja tako društvo naleti, vključno z možnostjo sodelovanja $\mathrm{v}$ javnih programih in $\mathrm{v}$ njihovem spreminjanju. Strukturni dejavniki npr. pojasnijo, zakaj lahko v podobnih okoliščinah pride do podobnega pojavljanja tovrstnega društva, medtem ko je človekovo delovanje tisto, ki razloži, zakaj lahko ta društva delujejo različno oz. se sploh ne pojavijo v nekem okolju. Ker SI implicirajo sodelovanje in povezovanje akterjev iz različnih sektorjev, je zelo pomembna pripravljenost konkretnega institucionalnega okolja na sodelovanje in povezovanje, po drugi strani pa tudi osebne kompetence sodelovanja akterjev, ki inovacijo začenjajo. Na to konstelacijo zunanjih in notranjih dejavnikov kaže tudi ugotovitev, da je SI emergenten in kontekstualno določen pojav.

Medtem ko je človekovo delovanje (agency) najpogosteje razumljeno in obravnavano kot osebno delovanje (personal agency), ki se izvaja individualno, pa Bandura (2000) v svoji kognitivni teoriji opredeljuje tudi drugo, kolektivno obliko delovanja, ki je posebej relevantna za SI. Kolektivno delovanje pomeni vzajemno odvisno delovanje za dosego želenega, kar presega moči posameznika. Bandura kot ključno sestavino tega kolektivnega delovanja opredeljuje skupno prepričanje in vero v kolektivno moč in kolektivno 
zmožnost oz. kolektivno delujočnost (collective efficacy) za doseganje cilja. Kolektivni dosežek ni le rezultat skupnega znanja in zmožnosti posameznikov, ampak tudi interaktivne, usklajevalne in sinergistične dinamike njihovih transakcij. Prav pomanjkanje slednjega pojasnjuje, zakaj zelo sposobni posamezniki lahko kot skupina in kot celota delujejo slabo.

Skupno prepričanje ljudi v svojo kolektivno zmožnost bistveno vpliva na to, kakšno prihodnost želijo doseči s kolektivnim delovanjem, koliko svojih virov so pripravljeni uporabljati in koliko naporov vložiti v skupni podvig, pa tudi na to, koliko so odporni na začetne neuspehe ali ovire in koliko podležejo malodušju, ki lahko ljudi odvrača ob težjih družbenih problemov. (Bandura, 2000: 76)

Prepričanje v kolektivno delujočnost in njegov odločilni pomen za kolektivno delovanje se $\mathrm{v}$ primeru SI srečujeta $\mathrm{z}$ dvema specifično težavnima okoliščinama. Prva okoliščina je ta, da - drugače kot pri mnogih drugih oblikah kolektivnega delovanja - SI vsebujejo element novega, neznanega, kar zahteva večji napor za obvladovanje tveganja in za učenje. Zato imajo pri SI posebej pomembno vlogo procesi skupnega učenja in pridobivanja znanja, ki niso pomembni samo vsebinsko - za oblikovanje skupnih ciljev in delovanje za njihovo doseganja, ampak tudi v smislu skupinske dinamike in kohezivnosti, kot vir povezovanja in gradnje zaupanja med vključenimi in njihove kolektivne zmožnosti. Druga specifična okoliščina je, da SI implicirajo sodelovanje med akterji iz različnih sektorjev, zato je treba premoščati velike razlike, ki so med njimi, glede znanja, načina dela, oblik organizacije in organizacijske kulture. Vse to so naloge vodenja, ki zahteva specifične pristope in veščine. Pridobivanje znanja in vodenje sta torej procesa, ki sta za SI konstitutivnega pomena. V naslednjih razdelkih ju posebej obravnavamo in izpostavljamo nekatere nove modele in prakse na področju učenja in vodenja, ki nastajajo v sodobnih družbah in iz katerih črpajo tudi SI.

Po drugi strani pa k proučevanju nekaterih ključnih vprašanj SI lahko veliko prispevajo tudi koncepti, ki izhajajo iz povsem drugega teoretskega okvira. Gre za teorijo kompleksnosti, ki na nov način opredeljuje vprašanja npr. samoorganizacije, povezovanja, učenja in vodenja. Modele in metode teorije kompleksnosti, sprva razvite za proučevanje kompleksnih sistemov kot takih, torej abstraktno in ne glede na področje, so sčasoma začeli uporabljati in dograjevati na različnih področjih od biologije, fizike in računalništva do antropologije in poslovnih ved (Schneider in Bauer, 2007). Teorija kompleksnosti daje vpogled $\mathrm{v}$ delovanje in spreminjanje kompleksnih družbenih sistemov kot posledice decentraliziranega nadzora in samoorganizacije in obravnava vprašanja nepredvidljivosti, neurejenosti in nestabilnosti, torej 
vprašanja, ki jih tradicionalni pristopi k proučevanju družbenih sprememb niso zadovoljivo zajemali (Preskill in Beer, 2012; Espinosa et al., 2011).

Osrednja kategorija v teoriji kompleksnosti je »kompleksni adaptivni sistem« (glej npr. Lacayo et al., 2008; Lichtenstein, 2006; Eidelson, 1997; Johansen in Rausand, 2014). "Kompleksnost" označuje to, da sistem vključuje veliko majhnih delov, ki nimajo skupnega centralnega nadzora (npr. jata ptic ali finančni trgi). Razporeditev teh delov je posledica njihovih lokalnih medsebojnih interakcij, ki pa jih usmerjajo in sinhronizirajo neka enostavna načela. Določena urejenost delov se torej pojavi kot rezultat samoorganizacije - individualnega ravnanja po teh načelih; urejenost vznikne od spodaj navzgor in ne zaradi centralnega nadzora. En od pomembnih nalog raziskovalnih modelov je identificirati ta načela, ki v različnih kontekstih pojasnijo nastanek samoorganizacije oz. konkretne urejenosti. "Adaptivnost « sistema pa označuje to, da se sistem prilagaja okolju na način, da ohranja homeostazo (ohranjanje ravnovesja s samoregulacijo s pomočjo avtomatskih povratnih zank). Ta notranja dinamika sistema je odvisna od interakcij med posameznimi deli, ki se prav tako prilagajajo in odzivajo z medsebojnim sodelovanjem ali tekmovanjem. Vsak sestavni del v kompleksnem adaptivnem sistemu deluje relativno avtonomno in je zmožen indi12 vidualiziranega odzivanja na lokalno dogajanje. Tako se razvijejo strukture interakcij, ki proizvedejo spontano prilagoditveno prerazporeditev med člani, ne da bi tu deloval kakršenkoli centralni nadzor.

Teorija kompleksnosti prinaša novosti tudi v proučevanje družbenih sistemov, če so razumljeni kot kompleksni adaptivni sistemi (Schneider in Bauer, 2007; Manson, 2001). Teorija kompleksnosti izpostavlja učenje in prilagajanje na ravni akterja, ki mu priznava zmožnost relativno avtonomnega odzivanja in smotrnega delovanja; prepoznava večplastno naravo družbenih sistemov v smislu, da lahko pojavi na višjih ravneh vzniknejo iz interakcij na nižjih ravneh; z modeliranjem skuša identificirati vzorce večkratnih pozitivnih in negativnih povratnih zank, ki so prisotne v interakcijah med deli. V kontekstu teorije kompleksnosti je vprašanje družbene spremembe razumljeno kot kompleksen, nelinearen, emergenten in samoorganizirajoč se proces. Poudarek je na povezavah in interakcijah med posameznimi deli kompleksnih adaptivnih sistemov, na tem, kako se med deli oblikujejo vzorci odnosov in kako se v celoti vzpostavi urejenost in decentraliziran nadzor.

Za razumevanje SI je teorija kompleksnosti relevantna zaradi naslednjih razlogov (Preskill in Beer, 2012). Najprej, SI naslavljajo probleme, ki so komplicirani (imajo mnogo spremenljivih delov) in kompleksni (vključujejo soodvisne variable, številne dejavnike, ki so hkrati v medsebojni interakciji in med katerimi je mnogo povratnih zank). Nadalje, poti do rezultatov in tudi sami rezultati so nepredvidljivi in emergentni. Pri obravnavi kompleksnih sistemov in rešitev je na delu veliko dejavnikov in vplivov, zato 
je njihovo delovanje manj predvidljivo, ponovitev določenih korakov pa ne pripelje nujno do istih učinkov; majhne spremembe ali začetne razlike lahko pripeljejo do velikih in nepričakovanih sprememb, saj v sistemu ni mogoče prepoznati vseh medsebojnih vplivov med deli.

Na osnovi koncepta kompleksnega adaptivnega sistema pa nastajajo tudi dejanske SI, v katerih se vzpostavlja povezovanje in družbeno delovanje različnih akterjev z opredeljenim smotrom. Več o tem bo govora v naslednjem razdelku, tu izpostavimo le primer »ekosistema«. Kot navaja Goblle (2014: 1) je

"ekosistem" definiran kot kompleksna množica odnosov med življenjskimi viri, življenjskimi okolji in prebivalci nekega področja, katerih funkcionalni cilj je ohranjati stanje, ki vzdržuje ravnovesje.

Še bolj specifičen pa je »inovacijski ekosistem « - skupnost, ki jo sklenejo različni subjekti z namenom, da si delijo množico komplementarnih tehnologij ali kompetenc; $v$ taki dinamični in kompleksni skupnosti se med subjekti vzpostavljajo kompleksni, v določenem delu spojeni odnosi, ki temeljijo na sodelovanju, zaupanju in soustvarjanju nove vrednosti (Ho ecker, 2019; Durst in Poutanen, 2013; Jackson, 2011)

\section{Nehierarhično, decentralizirano vodenje}

Drugače kot stabilno okolje, v katerem je centralizirano odločanje in vodenje iz ene točke lahko učinkovito, pa dinamična okolja z več deležniki zahtevajo manj hierarhično in decentralizirano strukturo, v kateri je moč odločanja porazdeljena med več enot; v podporo decentraliziranemu odločanju se pojavljajo nove organizacijske strukture - t.i. postmoderne organizacije (Bauwens, 2005). V poslovnem svetu je decentralizirano odločanje vprašanje korporativnega vodenja, $v$ javnih organizacijah in javnih politikah pa vprašanje, kako zagotoviti sodelovanje širšega kroga akterjev (Rychkova in Zdravkovic, 2017), npr. v zdravstvenem varstvu (Rouse, 2008). Za SI in za možnosti povezovanja in sodelovanja različnih akterjev je nehierarhično decentralizirano vodenje izrednega pomena, medtem ko centralizirano hierarhično vodenje predstavlja veliko oviro. Zato ni naključje, da se prav ob socialnih inovacijah pojavljajo tudi nove oblike nehierarhičnega vodenja.

\section{Novi modeli decentraliziranega vodenja $v$ organizacijah, sociokracija}

Vprašanja glede strukture vodenja znotraj organizacij in med njimi se na novo odpirajo ne le pod vplivom teorije kompleksnosti, ampak tudi zaradi možnosti uporabe internetne tehnologije, ki je lahko specifično prilagojena 
bolj centraliziranemu ali pa bolj decentraliziranemu modelu vodenja. Organizacija, ki želi zagotavljati stalno vključenost uporabnikov in partnerskih organizacij ter imeti in ponujati stalen vpogled $\mathrm{v}$ učinke delovanja, bo to zelo težko dosegala ob hierarhični strukturi in centraliziranem odločanju (Rychkova in Zdravkovic, 2017).

Potreba po nehierarhičnem vodenju se izraža $\mathrm{v}$ številnih drugih novih oblikah povezovanja, pa tudi $\mathrm{v}$ teorijah in konceptih poslovnega vodenja, npr. kompleksno voditeljstvo (complexity leadership) (Lichtensetein et al., 2006; Bengtsson in Kock, 2000). Tako se pojavljajo npr. sodelovalna omrežja in virtualne organizacije, katerih značilnost je, da vključujejo samostojna telesa oz. kompletne organizacije, ki pa si delijo določene vire in znanja pri doseganju svojih ciljev. Tako izraz »koopeticija izraža povezave med dvema ali več organizacijami, ki delno sodelujejo npr. z uporabo skupnih virov, hkrati pa glede specifičnih ciljev med seboj tudi tekmujejo. V ospredje prihajajo oblike vodenja, pri katerih se spoštujeta delna avtonomija in samoorganizacija določenih delov ali ravni, pa tudi horizontalne povezave med člani, ki so na isti organizacijski ravni (kolegi, sosedje, sodelavci - peers).

Tudi sociokracija (Endenburg, 1998; Rios, 2011) je nov model decentraliziranega vodenja. Veliko ga uporabljajo v javnih, zasebnih, neprofitnih in

14 skupnostnih organizacijah, v katerih predstavlja eno od ključnih alternativ tradicionalni organizacijski strukturi. Moč odločanja je porazdeljena po organizaciji, veljajo pa tri načela: 1) do odločitve pride, ko ni več bistvenih ugovorov in dajo udeleženci pristanek; 2) organizacijo sestavlja hierarhija polavtonomnih krogov; 3) vsak krog je povezan s krogoma više in niže prek posameznikov, ki delujejo kot polnopravni člani pri odločitvah obeh krogov. V primerjavi s tradicionalnimi odbori, katerih člane lahko imenuje vodilni, so sociokratski krogi samoupravni, njihovi člani v drugih krogih pa so izvoljeni.

\section{Upravljanje (vladovanje, governance)}

Vprašanje nehierarhičnega in decentraliziranega vodenja ter koordinacije različnih akterjev je za socialno politiko nasploh postalo zelo relevantno že s trendom pluralizacije blaginje in odpiranjem prostora za raznovrstne akterje. Koordinacija različnih akterjev iz politične, gospodarske in civilno družbe sfere od države in javnega sektorja terja uporabo nehierarhičnih struktur in procesov delovanja. Te sodobne oblike upravljanja oz. vodenja (governance) so pri nas večkrat poimenovane vladovanje (Bačlija, Brajnik et al., 2013). Izraz "governance« oz. vladovanje označuje

kolektivno odločanje in oblikovanje politik, pri katerih mora vlada svojo oblast deliti s širokim krogom akterjev iz tržnega, civilnodružbenega 
in prostovoljskega sektorja in uporabiti manj hierarhične in bolj horizontalne, kooperativne in dialoške oblike vladanja. (Oosterlynck et al., 2013: 29)

Te bolj vključujoče oblike vodenja se v javnih oz. področnih politikah vse bolj uveljavljajo, seveda v zelo različnih oblikah in tudi nacionalnih specifikah.

Lokalno vladovanje (local governance) je širši koncept, opredeljen kot oblikovanje in izvrševanje kolektivne akcije (odločanja) na lokalni ravni; zajema posredne in neposredne vloge formalnih institucij lokalne oblasti in njene hierarhije, pa tudi vloge neformalnih norm, omrežij, skupnostnih organizacij in sosedskih združenj pri uresničevanju kolektivnega delovanja, ki poteka v okviru odnosov med državljani in oblastjo v obliki kolektivnega odločanja ter zagotavljanja javnih dobrin in storitev (Brezovšek, 2012).

\section{Sodelovalno vodenje in vloga javnega sektorja pri pospeševanju sodelovanja med več akterji}

Ker nastanek in razvoj SI zahtevata manj hierarhične načine vodenja, ki podpirajo povezovanje in sodelovanje med različnimi akterji, Sørensen in Torfing (2015) izpostavljata možnost in odgovornost javnega sektorja, da te procese podpre $z$ uporabo "sodelovalnega vodenja« (collaborative leadership). Ta način vodenja vključuje posebne vodstvene kompetence, ki omogočajo, da se skozi sodelovanje različnih akterjev pojavijo in uresničujejo nove kreativne rešitve onkraj ustaljenih praks.

Sodelovalno vodenje je specifično namenjeno kot podpora sodelovanju. Ta način vodenja vključuje posebne vodstvene kompetence, ki omogočajo, da se skozi sodelovanje različnih akterjev pojavijo in uresničujejo nove kreativne rešitve onkraj ustaljenih praks. Cilj sodelovalnega vodenja je izoblikovati primerne institucionalne "arene« za sodelovalno vodenje; poleg tega mora olajševati procese sodelovanja s poudarjanjem vzajemne odvisnosti, z graditvijo zaupanja in z razvijanjem razumevanja skupnega cilja; ker se pri tem porajajo konflikti in nasprotja, je potrebna tudi mediacija konfliktov. Sørensen in Torfing (2015) menita, da lahko javni sektor ponuja kritično podporo kolaborativnemu razvijanju inovacij tako, da vodje in menedžerji v javnih ustanovah sprejemajo več konkretnih vlog v tej smeri. Vloga povezovalca, sklicatelja (convener), je, da pripelje skupaj relevantne akterje ter med njimi sproži interakcije in izmenjavo informacij, pogledov in idej. Vloga organizatorja (facilitatorja) je, da pripravi akterje do sodelovanja s tem, da konstruktivno upravlja $\mathrm{z}$ njihovimi razlikami in jih vplete $\mathrm{v}$ procese vzajemnega učenja onkraj skupnega začetnega imenovalca. Vloga pospeševalca (catalyst) je, da ustvari primerne moteče dejavnike, ki bodo akterje 
spravili iz cone udobja in jih prisilili h kreativnemu razmišljanju in razvijanju pogumnih novih rešitev.

Poleg sodelovalnega sloga vodenja pa Sørensen in Torfing (2015) izpostavljata tudi druge specifične sloge vodenja, s katerimi lahko odgovorni $\mathrm{v}$ javnem sektorju bistveno doprinesejo $\mathrm{k}$ socialnim inovacijam. Z distributivnim slogom vodenja lahko vodje in menedžerji $\mathrm{v}$ javnem sektorju pospešujejo sodelovanje med drugimi akterji tako, da si z njimi delijo vodstvene funkcije in omogočajo samoorganizacijo pri projektih na nižjih ravneh; končni cilj distributivnega vodenja je spodbuditi samoregulacijo. Horizontalni slog vodenja ima za cilj spodbuditi in podpreti interaktivne in sodelovalne procese med kolegi (peers); horizontalno vodstvo projektov, skupin in omrežij povezuje npr. predstavnike različnih poklicev in različnih vlog (npr. uporabnikov in izvajalcev storitev), da v sodelovanju in interakciji iščejo nove rešitve problemov. Povezovalni slog vodenja ima za cilj trajneje povezati različne skupine in organizacije, s poudarkom na čezsektorskem povezovanju pri iskanju novih rešitev kompleksnih problemov. Uspešno vodenje temelji na začetnem soglasju o tem, kaj je problem, in na iskanju primerne oblike za proces sodelovanja, upoštevaje kompetence udeleženih. Zagotavljati mora kontinuirane aktivnosti, v katerih se utrjuje medse16 bojno zaupanje, strukture sodelovanja pa so prožne in odprte za nove člane in za naslednje vodje.

Uveljavlja se tudi vzorec sodelovalnega vladovanja (collaborative governance), pri katerem se srečujejo deležniki iz javnega in zasebnega sektorja in se kot kolektivni forum vključijo v proces odločanja, ki je usmerjeno k gradnji soglasja (Ansell in Gash, 2008).

\section{Nove oblike in primeri pridobivanja in uporabe znanja $\mathrm{s}$ povezovanjem}

Socialne inovacije so praktične spremembe, zato je zanje relevantna praktična uporabnost znanja. Tako se v luči praktične uporabnosti odpirajo vprašanja, povezana z načini pridobivanja znanja, z možnostmi njegove uporabe, in tudi temeljna vprašanja, kaj je znanje in kaj vse vsebuje. Za nove prakse je relevantno izhodišče v Bandurovi socialni teoriji učenja, ki učenje razume kot kognitivni proces, ki se dogaja v socialnem kontekstu; ljudje se vedenja oz. obnašanja učijo v socialnem okolju, drug od drugega, z opazovanjem, posnemanjem, modeliranjem (Bandura, 1977). Pomembno je tudi razlikovanje med tihim (tacit) znanjem in eksplicitnim znanjem (Snowden, 2002). "Tiho« je tisto znanje, ki ga je posameznik ponotranjil in ga pri nekem opravilu uporablja, ne da bi se ga morda sploh zavedal. „Eksplicitno« pa je znanje, na katerega se posameznik osredotoča zavestno in ga tudi zlahka sporoči drugim (npr. znanje pri akademskem predmetu). Medtem ko je eksplicitno 
znanje v središču pozornosti v akademskih okoljih, pa imajo »tiha« znanja pomembno mesto $v$ različnih (poklicnih) praksah, vključno z vodenjem.

Pridobivanje raznovrstnega znanja in upravljanje z znanjem (t.i. knowledge management) doživljata izredno dinamičen razvoj, še posebej v poslovnih in organizacijskih vedah, kjer nastopata $v$ funkciji boljšega delovanja organizacij; ugotavljajo npr., kako je z organizacijskim učenjem in s strateškim upravljanjem mogoče znanje deliti med različnimi deli neke organizacije, pa tudi med organizacijami (Girard in Girard, 2015; Spender, 1993, 1996). Upravljanje znanja se uveljavlja tudi na drugih področjih in $\mathrm{v}$ različnih oblikah. V nadaljevanju predstavljamo dve specifični organizacijski obliki, ki sta se v evropskem prostoru v zadnjih letih zelo razširili in vsebujeta ključno dimenzijo socialne inovacije - novo obliko povezovanja med različnimi tipi akterjev. To sta »skupnost prakse« in »živi laboratorij«.

\section{Skupnost prakse}

Skupnost prakse (community of practice, COP) je vse bolj razširjen pristop k znanju in učenju, osredinjen na ljudi in družbene strukture, ki jim omogočijo, da se učijo drugi z drugim in drug od drugega (Duguid, 2005). Skupnosti prakse tvorijo ljudje, vključeni v proces skupinskega učenja na nekem specifičnem področju delovanja; imajo skupno zanimanje (skrb, strast) za nekaj, kar počnejo in se učijo, kako to početi bolje in ob tem, ko so $\mathrm{v}$ redni interakciji (Wenger, 2011).

"Skupnost prakse« sta kot koncept uveljavila Lave in Wenger (1991) in ga definirala s tremi dimenzijami. Prva dimenzija je specifična domena, skupno področje zanimanja, ki daje identiteto tej skupnosti. Člani prepoznavajo in cenijo kompetence, ki so specifične za to domeno, in se jih učijo drug od drugega. Druga dimenzija je skupnost; člani se zaradi skupnega zanimanja za to področje udeležujejo skupnih aktivnosti in diskusij, si medsebojno pomagajo, delijo informacije, in tako gradijo medsebojne odnose, ki jim omogočajo, da se drug od drugega učijo. Tretja dimenzija je praksa - člani prakticirajo nekaj, kar jim je skupno in lahko za to prakso razvijajo skupni nabor virov: izkušenj, zgodb, primerov, orodij, načinov lotevanja problemov. Primer skupnosti prakse so npr. medicinske sestre, ki se redno dobivajo ob kosilu v bolnišnični menzi in se pogovarjajo o negi bolnikov; tako si delijo množico primerov, zgodb in spoznanj, ki postanejo del skupnega vedenja in znanja njihove prakse.

Tako pojmovane skupnosti prakse sicer obstajajo že od nekdaj, jih pa dandanes močno popularizirajo poslovne in organizacijske vede; podpirajo in poznajo jih tudi pod drugimi nazivi - omrežje učenja, tematske skupine itd. (Mercieca, 2017). Skupnosti učenja danes nastajajo v različnih oblikah, so majhne ali velike, lokalne ali globalne, se srečujejo osebno ali 
prek interneta, nekatere so formalno prepoznane in finančno podprte, druge povsem neformalne in nevidne. Kot tipične primere aktivnosti, ob katerih se razvijejo skupnosti prakse, Wenger (2011) navaja reševanje specifičnega problema, iskanje informacij, poizvedovanje za informacijami in izkušnjami, medsebojne obiske praktikov, skupno uporabo specifičnih virov, preudarjanje razvojnih možnosti.

\section{Primer »skupnosti prakse" - inovativni projekti mešanih stanovanj $v$ Utrechtu}

Kot navajajo Davelaar in drugi (2019), se je mesto Utrecht odločilo povečati sklad primernih socialnih stanovanj in ustvariti vključujoče soseske z mešanimi kolektivnimi stanovanjskimi projekti za "redne« in tudi ranljive skupine, kot so brezdomci ter ljudje z mentalno zdravstvenimi težavami. Tako so izpeljali več projektov "mešanega stanovanja«, ki imajo določene značilnosti: gre za stanovanjske projekte $\mathrm{z}$ do 500 enotami; tu najdejo dom različne skupine ljudi, ki namerno živijo en ob drugem, se povezujejo in vključujejo v skupne dejavnosti. Na tej osnovi so potem oblikovali »skupnost prakse mešanega stanovanja«, ki je vključevala raziskovalce, stano-

18 valce ter strokovnjake (upravniki, terenski delavci na področju mentalnega zdravja, socialni delavci in drugi) iz šestih izvedenih projektov mešanega stanovanja. $\mathrm{V}$ daljšem procesu sestajanja in pogovarjanja so $\mathrm{v}$ tej skupnosti prakse identificirali socialne strukture in mehanizme, ki omogočijo oblikovati socialno vzdržno, varno in privlačno stanovanjsko okolje tako za redne kot tudi ranljive stanovalce. Na tej osnovi so podali priporočila za izboljšavo in nadaljnjo širitev modela mešanih stanovanjskih projektov.

\section{Živi laboratoriji (Living labs)}

V Evropski mreži živih laboratorijev (European Network of Living Labs (ENoLL)) je dejavnih okoli 440 živih laboratorijev (LL). Opredeljeni so kot na uporabnike osrediščeni, odprti inovacijski ekosistemi, ki temeljijo na sistematičnem pristopu koprodukcije z uporabniki in povezujejo raziskovalne in inovacijske procese $\mathrm{v}$ realnih življenjskih skupnostih in okoljih. LL so oboje: praktično delujoče organizacije, ki podpirajo in izvajajo odprte sodelovalne inovacije, pa tudi realna življenjska okolja oz. »arene«, v katerih je mogoče uporabniško usmerjene inovacije opazovati, z njimi eksperimentirati in iskati nove rešitve (Ruijsink in Smith, 2016). Delujejo kot posredniki med državljani, raziskovalnimi organizacijami, podjetji, mesti in regijami pri skupnem soustvarjanju nove vrednosti, oblikovanju prototipov in pri njihovemu preverjanju (European Network of Living Labs, 2019a). V mreži je identificiranih devet tematskih področij delovanja živih laboratorijev: 
zdravje in blaginja; pametna mesta in regije; kultura in ustvarjalnost; energija; mobilnost; družbena vključenost; družbene inovacije; vlada; izobraževanje. Pri uveljavljanju živih laboratorijev so imele odločilno vlogo finančne spodbude, ki so v okviru evropskega raziskovalnega programa Horizon 2020 namenjene projektom, ki sledijo vseevropski strategiji Odgovorno raziskovanje in inoviranje (Responsible Research and Innovation, RRI) Osnova strategije je, da inovacije usmerjajo uporabniki. Zato

RRI implicira, da družbeni akterji (raziskovalci, državljani, oblikovalci politik, gospodarstvo, organizacije tretjega sektorja itd.) skupaj sodelujejo skozi celoten proces raziskovanja in inovacije zato, da ta proces in njegove rezultate bolje uskladijo z vrednotami, potrebami in pričakovanji družbe. (Evropska komisija, 2019)

Strategija usmerja skupnost uporabnikov h koprodukciji, pri tem deležniki uporabljajo različne metode in orodja za vključevanje uporabnikov; vsekakor pa je potrebno stopnjo vključenosti uporabnikov ocenjevati in vrednotiti, za kar so potrebne posebne metode ocenjevanja (Salminen et al., 2011).

V Sloveniji se živi laboratoriji še niso razvili. Med 440 člani v evropski mreži LL je iz Slovenije en sam in tudi ta povsem tehnološke narave. Tudi Raziskovalna in inovacijska strategija Slovenije (RISS), ki se izvaja skozi model pametne specializacije S4 (GOV.SI, 2017; GOV.SI, 2019), opredeljuje deležnike bistveno ožje od evropske RRI in jih eksplicitno omejuje na partnerstva med gospodarstvom, institucijami znanja in državo. Ne vključuje civilne družbe in organizacij tretjega sektorja, razvoj inovacij pa postavlja v ožji okvir gospodarstva in podjetij. Strategija S4 je izrecno opredeljena kot

izvedbeni načrt za prehod $v$ visoko produktivno gospodarstvo na podlagi krepitve inovacijske sposobnosti, spodbujanja transformacije in diverzifikacije industrij $v$ nove dejavnosti ter rasti novih in hitro rastočih podjetij.

Tak okvir ne priznava pomena družbenih inovacij in jih ne podpira.

\section{Primer socialne inovacije v okviru živih laboratorijev:}

AIPA (European Network of Living Labs, 2019b) je en izmed šestih živih laboratorijev oskrbe (Care Living Labs) v Belgiji. Cilj teh laboratorijev je spodbujati inovacije, ki odgovarjajo na izzive staranja in zadevajo stanovanje in okolje. AIPA omogoča testiranje, katere infrastrukturne, socialne in družbene okoliščine so nujne za to, da se bodo ljudje lahko starali na domu; 
cilj je starejšim omogočiti, da živijo v prilagojenih stanovanjih, da so stanovanja in oskrba cenovno dosegljivi in da prikrajšane skupine pri tem ne bodo izolirane. Ustvarja eksperimentalno okolje za podjetja in oskrbovalne organizacije, ki želijo razumeti in upoštevati potrebe starejših v njihovih domačih razmerah. Ponuja podporo pri hitrejši implementaciji, prilagajanju in vrednotenju inovacij. Omogoča demonstracijska stanovanja z najnovejšo infrastrukturo in storitvami, ki jih lahko starejši in oskrbovalci preizkusijo.

\section{Sklep}

Zelo obširna in pestra literatura, ki se v zadnjem desetletju ukvarja s SI, kaže na veliko kompleksnost tega pojava v smislu, da ga označuje veliko število lastnosti in mnogotere dimenzije vpetosti v družbeno okolje. Enostavna osnovna opredelitev SI je, da so to inovacije, ki so socialne tako po rezultatih kot po sredstvih; njihov zastavek je izboljšanje blaginje oz. reševanje neke nove družbene potrebe, in to na nov način, z novimi povezavami med akterji različnih sektorjev, ob večji vlogi in krepitvi moči samih ljudi, ki jih to prizadeva. Literatura navaja še druge značilnosti SI, zlasti da vključuje tako nastanek ideje kot praktično spremembo, da je kontekstualno določena ter po poteku kratkotrajna ali trajna. Izpostavlja tudi posebnosti, ki SI razlikujejo od drugih inovacij. Drugače kot pri tržnih imajo SI značilen zastavek (tj. izboljšati blaginjo ob večji vključenosti prizadete skupine); zadevajo predvsem storitve in ne proizvodov; bolj kot na enkratne transakcije se navezujejo na odnose in akterje v določenem družbenem kontekstu. Pač pa imata zaupanje in skupinska pripadnost pomembni vlogi pri sprejemanju obeh vrst inovacij. Za razliko od sistemskih inovacij na področju blaginje je v SI pomembna samoorganizacija in sprožanje sprememb od spodaj navzgor; SI vnašajo v neko okolje enkratne in posebne spremembe, zato implicirajo več negotovosti in neznanega, pogost sprožilec sprememb pa je skupna izkušnja iz vsakdanjega življenja ljudi.

Pomembna značilnost socialnih inovacij je, da predstavljajo praktično spreminjanje, prakso, aktivnost, delovanje. SI je princip, ki strukturira kolektivno akcijo (Chambon et al., 1982). To, da socialna inovacija implicira delovanje, je posebej relevantno z vidika sociološke teorije in vprašanja, kako pojav pojasniti. Medtem ko je razumevanje pojava SI z vidika zgodovinskega razvoja sistemov blaginje že obravnavano (pregledno o tem v Mandič in Hlebec, 2020), pa se v tem članku osrediščamo na vidik delovanja.

Naše osrednje zanimanje je namenjeno vprašanju, kako socialna inovacija vznikne in se razvija v družbenem okolju. Ob naslonitvi na strukturacijsko teorijo smo se odgovoru na to vprašanje približali z opredelitvijo socialne inovacije kot oblike družbenega delovanja. Še podrobnejšo umestitev smo našli v Bandurovi opredelitvi kolektivnega delovanja kot vzajemno 
odvisnega delovanja za doseganje želenega cilja, ki presega moči posameznika. Ključni element tega kolektivnega delovanja je po Banduri skupno prepričanje v kolektivno moč delovanja za dosego cilja (collective efficacy, tj. kolektivna delujočnost). Ker je skupno prepričanje v kolektivno delujočnost $v$ primeru SI posebej oteženo zaradi njenih dveh specifik - da se nanaša na nekaj novega in neznanega in da vzpostavlja nove povezave med akterji iz različnih sektorjev -, imata toliko večjo vlogo dva mehanizma reševanja teh težav: skupno učenje in decentralizirano vodenje. Ta dva dejavnika pa kot ključna za spremembe izpostavlja tudi teorija kompleksnosti.

Dejavniki, ki pojasnjujejo uspešnost in moč SI, segajo onkraj neposrednega področja blaginje na druga področja. SI - kot praktične spremembe v realnih okoljih - terjajo uporabo in razvoj tistih specifičnih modelov družbene organizacije, vodenja ter pridobivanja in uporabe znanja, ki omogočajo praktično spreminjanje ob povezovanju različnih akterjev. Za sodelovanje več akterjev so pomembne sodelovalne oblike vodenja, ki so z svojo vključujočnostjo in nehierarhičnostjo še posebej izziv za akterje iz javnega sektorja. Odgovornost javnega sektorja za razvoj SI je velika, saj lahko z uporabo svojih virov odigra nekaj vlog (npr. sklicatelj, povezovalec, organizator, facilitator, pospeševalec itd.), ki so ključne za razvoj SI, še posebej pomembno pa je ustvarjanje povezovalnih struktur.

Med ključnimi dejavniki, ki omogočajo skupno artikuliranje potreb in delovanje $\mathrm{v}$ okviru SI, sta tudi pridobivanje in uporaba skupnega znanja udeležencev, vključno z upoštevanjem in povezovanjem različnih področij in vrst znanja (npr. praktičnih veščin in akademskega znanja; družboslovja in tehnologije; strokovnjakov in laikov/uporabnikov/prebivalcev). Razvijajo se nove oblike in modeli skupnega učenja. Za vključevanje in sodelovanje predstavnikov različnih znanstvenih disciplin pa je pomembno priznavanje obstoja različnih znanj in spoznavnih temeljev, torej epistemološki pluralizem (Spender, 1998) ter uporaba problemsko, ne pa disciplinarno uokvirjenega pristopa. Paradigmatični primeri takšnega povezovanja ob novih oblikah vodenja in pridobivanja in uporabe znanja so skupnosti prakse in živi laboratoriji.

V naravi SI je, da so specifične; so plod konkretnih specifičnih iniciativ, ki so lahko uspele le ob ustreznem podpornem okolju, saj se vanj institucionalno in prostorsko vpenjajo. SI imajo močno lokalno in skupnostno komponento; lokacija in prostor vsakdanjega življenja sta pogosto podlaga za skupno izkušnjo, za povezovanje in skupno artikuliranje problemov in rešitev ter za kolektivno delovanje. Zelo pomemben je obstoj povezovalnih struktur oz. pripravljenost na njihovo oblikovanje v okviru lokalnega sistema blaginje. Tako se lokalni sistem blaginje izpostavlja kot najbolj relevantna entiteta za analizo SI. Kot specifični tip SI lahko izpostavimo tudi inovacijski ekosistem, ki kot koncept in kot že razširjen pojav odpira povsem nove horizonte razumevanja in delovanja $v$ družbi. 
SI so tudi nov izziv za sociologijo. Najprej je tu soočenje s teorijo kompleksnosti. Po eni strani je družboslovju ta teorija tuja, saj v njeni spoznavnoteoretski osnovi družba ni vnaprej spoznana kot svojevrsten, poseben pojav, pojav »sui generis«. Po drugi strani pa ta teorija prinaša v ospredje obravnave mnogo tem, ki so relevantne za družbeni razvoj. Še več, pojave, kot so npr. samoorganizacija, nehierarhično vodenje, vplivanje od spodaj navzgor in sodelovanje teorija kompleksnosti privzema kot dejstva, medtem ko se v družboslovju in javnih politikah uveljavljajo počasi in le deloma uspešno.

Nadaljnji izziv za sociologijo je vključevanje sociologije med (raziskujoče?) akterje SI, saj to zahteva, da namesto disciplinarnega pristopa sprejme problemski pristop. Problemski pristop je s svojim epistemološkim pluralizmom dovolj širok, da se ob njem sociologi lahko pridružijo in povežejo z drugimi akterji ter $\mathrm{v}$ tem enotnem okvirju najdejo prostor za uporabo svojih specifičnih znanj in raziskovalnih metod. Poleg tega pa je lahko sociologija bolj dejavna $z$ aktivnejšo facilitacijsko vlogo sklicevalca in povezovalca različnih akterjev, kar je zelo pomembno ob siceršnji odsotnosti povezovalnih struktur. Na možnost facilitacijskega delovanja sociologije opozarja npr. Treviño (2013) in v tem vidi pomembno dopolnilo javne sociologije, ki svoje delovanje omejuje na javni dialog o reševanju družbenih problemov.

22 Konec koncev pa so socialne inovacije izziv tudi za tradicionalno, analitično usmerjeno sociologijo, saj so pojav, ki je nasploh le malo raziskan.

\section{LITERATURA}

Almirall, Esteve, Melissa Lee in Jonathan Wareham (2012): Mapping Living Labs in the Landscape of Innovation Methodologies. Technology Innovation Management Review 2 (9): 12-18.

Ansell, Chris in Alison Gash (2008): Collaborative Governance in Theory and Practice. Journal of Public Administration Research and Theory 18 (4): 543-571.

Bačlija Brajnik, Irena, Gaja Červ in Maja Turnšek (2013): „Governance«: vladanje, upravljanje, vladavina ali vladovanje? Družboslovne razprave 73 (29): 99-119.

Bandura, Albert (1977): Social Learning Theory. New York: General Learning Press. Bandura, Albert (2000): Exercise of Human Agency through Collective Efficacy. Current Directions in Psychological Science 9 (3): 75-78.

Barroso, José Manuel Durão (2011): Europe leading social innovation. Dostopno prek https://ec.europa.eu/commission/presscorner/detail/en/SPEECH_11_ 190, 15. 5. 2020.

Bauwens, Michel (2005): »The political economy of peer production.« CTheory, $12-1$.

Bengtsson, Maria, in Sören Kock (2000): „Coopetition« in Business Networks - to Cooperate and Compete Simultaneously. Industrial Marketing Management 29 (5): 411-426.

Berner, Erhard, in Benedict Phillips (2005): Left to their own devices? Community self-help between alternative development and neo-liberalism. Community Development Journal 40 (1): 17-29. 
Bežovan, Gojko, Jelena Matančević in Danijel Baturina (2016): Socijalne inovacije kao doprinos jačanju socijalne kohezije i ublažavanju socijalne krize u europskim urbanim socijalnim programima. Revija za socijalnu politiku 23 (1): 61-80.

Brandsen, Taco (ur.), Sandro Cattacin (ur.), Adalbert Evers (ur.) in Annette Zimmer (ur.) (2016): Social Innovations in the Urban Context. Cham: Springer.

Brezovšek, Marjan (2012): K državljanu usmerjeno lokalno vladovanje: evolucija lokalne oblasti. V: Miro Haček (ur.), Upravljavska sposobnost slovenskih občin: primeri dobrih praks, 11-28. Ljubljana: Friedrich Ebert Stiftung Zagreb in Fakulteta za družbene vede Ljubljana.

Chambon, Jean-Louis, Alix David in Jean-Marie Devevey (1982): Les innovations sociales. Paris: Presses universitaires de France.

Crnkovič, Deja (2009): Slavko Gaber: Predsednik društva Časovna banka Slovenije. Mladina 46: 9.

Davelaar, Maarten, Lia van Doorn, Aly Gruppen in Jeroen Knevel (2019): Welcome in my backyard: how having good neighbours can help ending homelessness. Editorial Universitat Politècnica de València, 168-172.

Duguid, Paul (2005): »The Art of Knowing«: Social and Tacit Dimensions of Knowledge and the Limits of the Community of Practice. The Information Society 21 (2): 109-118.

Durst, Susanne in Petro Poutanen (2013): Success factors of innovation ecosystems: A literature review. V: Riitta Smeds (ur.) in Olivier Irrmann (ur.), CO-CREATE 2013: The Boundary-Crossing Conference on CoDesign in Innovation, 27-38. Aalto: Aalto University.

Eidelson, Roy J. (1997): „Complex adaptive systems in the behavioral and social sciences." Review of General Psychology 1 (1): 42-71.

Endenburg, Gerard (1998): Sociocracy: The organization of decision-making. Delft: Eburon, 1998.

Espinosa, Angela, Pedro Pablo Cardoso, Elsa Arcaute in Kim Christensen (2011): Complexity approaches to self organisation: A case study from an Irish eco village. Kybernetes 40 (3/4): 536-558.

Evers, Adalbert (2005): Mixed Welfare Systems and Hybrid Organizations: Changes in the Governance and Provision of Social Services. International Journal of Public Administration 28 (9): 737-748.

Evers, Adalbert (ur.), Benjamin Ewert (ur.) in Taco Brandsen (ur.) (2014): Social Innovations for social cohesion: Transnational patterns and approaches from 20 European cities. Liege: EMES European Research Network.

Evers, Adalbert in Benjamin Ewert (2015): Social Innovation for Social Cohesion. V: Alex Nicholls (ur.), Julie Simon (ur.) in Madeleine Gabriel (ur.), New Frontiers in Social Innovation Research, 107-127. London: Palgrave Macmillan.

Giddens, Anthony (1981): A Contemporary Critique of Historical Materialism: Volume 1, Power, Property and the State. Berkeley, CA: University of California Press.

Girard, John in JoAnn Girard (2015): Defining knowledge management: Toward an applied compendium. Online Journal of Applied Knowledge Management 3 (1): 1-20. 
Gobble, MaryAnne M. (2014): Charting the Innovation Ecosystem, ResearchTechnology Management 57 (4): 55-59.

Hoffecker, Elizabeth (2019): Understanding Innovation Ecosystems: A Framework for Joint Analysis and Action. Cambridge: MIT D-Lab.

Hubert, Agnès (2010): Empowering people, driving change: Social innovation in the European Union. Bruselj: Evropska komisija.

Jackson, Deborah J. (2011): What is an Innovation Ecosystem? Dostopno prek https:// www.researchgate.net/profile/Deborah_Jackson2/publication/266414637 What_is_an_Innovation_Ecosystem/links/551438490cf2eda0df30714f.pdf, 15 . 5. 2020.

Jenson, Jane (2015): Social Innovation: Redesigning the Welfare Diamond. V: Alex Nicholls (ur.), Julie Simon (ur.) in Madeleine Gabriel (ur.), New Frontiers in Social Innovation Research, 89-106. London: Palgrave Macmillan.

Johansen, Inger Lise in Marvin Rausand (2014): Defining complexity for risk assessment of sociotechnical systems: A conceptual framework. Journal of Risk and Reliability 228 (3): 272-290.

Lacayo, Virginia, Rafael Obregón in Arvind Singhal (2008): Approaching social change as a complex problem in a world that treats it as a complicated one: The case of Puntos de Encuentro, Nicaragua. Investigación y Desarrollo 16 (2): 126-159.

24 ticipation. New York: Cambridge university press.

Lichtenstein, Benyamin B., Mary Uhl-Bien, Russ Marion, Anson Seers, James Douglas Orton, and Craig Schreiber (2006.) „Complexity leadership theory: An interactive perspective on leading in complex adaptive systems."

Mandič, Srna, Maša Filipovič Hrast (2018): Homeownership in multi-apartment buildings: control beyond property rights. Housing theory and society 36 (4): 401-425.

Mandič, Srna in Hlebec, Valentina (2020): Socialne inovacije kot prispevek k blaginji skupnosti . V Maša Filipovič Hrast (ur.) in Valentina Hlebec. (ur): Blaginja v skupnosti: razvojni vidiki in inovacije, 11-32. Ljubljana : Fakulteta za družbene vede, Knjižna zbirka Ost.

Manson, Steven M. (2001): Simplifying complexity: a review of complexity theory. Geoforum 32 (3): 405-414.

Mercieca, Bernadette (2017): What Is a Community of Practice? V: Jacquie McDonald (ur.) in Aileen Cater-Steel (ur.), Communities of Practice: Facilitating Social Learning in Higher Education, 3-25. Singapore: Springer.

Moos, A. I., in M. J. Dear (1986): Structuration theory in urban analysis: 1 . Theoretical exegesis. Environment and Planning A 18 (2): 231-252.

Moulaert, Frank (2010): Social innovation and community development: Concepts, theories and challenges. V: Frank Moulaert (ur.), Flavia Martinelli (ur.), Erik Swyngedouw (ur.) in Sara González (ur.), Can neighbourhoods save the city?, 4-16. London: Routledge.

Moulaert, Frank (2016): Social innovation: Institutionally embedded, territorially (re) produced. V: Diana MacCallum (ur.), Frank Moulaert (ur.), Jean Hillier (ur.) 
in Serena Vicari Haddock (ur.), Social Innovation and Territorial Development, 11-24. Padstow: Ashgate Publishing.

Moulaert, Frank, Bob Jessop in Abid Mehmood (2016): Agency, structure, institutions, discourse (ASID) in urban and regional development. International Journal of Urban Sciences 20 (2): 167-187.

Moulaert, Frank, Diana MacCallum, Abid Mehmood in Abdelillah Hamdouch (2013): General Introduction: The Return of Social Innovation as a Scientific Concept and a Social Practice. V: Frank Moulaert (ur.), Diana MacCallum (ur.), Abid Mehmood (ur.) in Abdelillah Hamdouch (ur.), The International Handbook on Social Innovation: Collective Action, Social Learning and Transdisciplinary Research, 1-6. Cheltenham: Edward Elgar Publishing.

Mulgan, Geoff (2015): Foreword: The Study of Social Innovation - Theory, Practice and Progress. V: Alex Nicholls (ur.), Julie Simon (ur.) in Madeleine Gabrisel (ur.), New Frontiers in Social Innovation Research, $\mathrm{x}$-xxi. London: Palgrave Macmillan.

Mulgan, Geoff, Simon Tucker, Rushanara Ali in Ben Sanders (2007): Social Innovation: What it is, Why it Matters and How It Can be Accelerated. London: The Young Foundation.

Oosterlynck, Stijn, Yuri Kazepov, Andreas Novy, Pieter Cools, Florian Wukovitsch, Tatiana Saruis, Eduardo Barberis in Bernhard Leubolt (2013): Exploring the multi-level governance of welfare provision and social innovation: welfare mix, welfare models and rescaling. ImPRovE Discussion Paper 13 (12): 1-41.

Pisano, Umberto, Lisa Lange in Gerald Berger (2015): Social Innovation in Europe: An overview of the concept of social innovation in the context of European initiatives and practices. Dostopno prek https://www.sd-network.eu/quarterly\%20 reports/report\%20files/pdf/2015-April-Social_Innovation_in_Europe.pdf, 20. 6. 2019.

Preskill, Hallie in Tanya Beer (2012): Evaluating social innovation. Washington: Center for Evaluation Innovation.

Rios, Melanie (2011): Sociocracy: A Permaculture Approach to Community Evolution. Communities 153: 20-23.

Rouse, William B. (2008): Health Care as a Complex Adaptive System: Implications for Design and Management. Bridge 38 (1): 18-25.

Rogers, Everett M. (2003): Diffusion of Innovations, Free Press, New York.

Ruijsink, Saskia in Adrian Smith (2016): Transformative Social Innovation: European Network of Living Labs. Dostopno prek http://www.transitsocialinnovation.eu/ resource-hub/european-network-of-living-labs, 15. 5. 2020.

Rychkova, Irina in Jelena Zdravkovic (2017): Towards decentralized IT governance in the public sector: a capability-oriented approach. V: Lazar Rusu (ur.) in Gianluigi Viscusi (ur.), Information Technology Governance in Public Organizations, 107-132. Cham: Springer.

Salminen, Juho, Suvi Konsti-Laakso, Marc Pallot, Brigitte Trousse in Bernard Senach (2011): Evaluating user involvement within living labs through the use of a domain landscape. Dostopno prek https://www.researchgate.net/ profile/Juho_Salminen/publication/224261808_Evaluating_user_involvement 
_within_living_labs_through_the_use_of_a_domain_landscape/links/0912f 510932f07b404000000.pdf, 15. 5. 2020.

Schneider, Volker in Johannes M. Bauer (2007): Governance: Prospects of complexity theory in revisiting system theory. 65th Annual National Conference of the Midwestern Political Science Association. Dostopno prek http://citeseerx. ist.psu.edu/viewdoc/download?doi=10.1.1.261.3726\&rep=rep1\&type=pdf, 15 . 5. 2020.

Sendi, Richard (2014): Socialna inovacija za boj proti diskriminaciji oseb z oviranostmi v grajenem okolju. Urbani izziv 25 (2): 48-57.

Snowden, Dave (2002): Complex Acts of Knowing - Paradox and Descriptive Self Awareness. Journal of Knowledge Management 6 (2): 100-111.

Sørensen, Eva in Jacob Torfing (2015): Enhancing Public Innovation through Collaboration, Leadership and New Public Governance. V: Alex Nicholls (ur.), Julie Simon (ur.) in Madeline Gabriel (ur.), New Frontiers in Social Innovation Research, 149-169. London: Palgrave Macmillan.

Spender, John-Christopher (1993): Competitive Advantage from Tacit Knowledge? Unpacking the Concept and Its Strategic Implications. Academy of Management Proceedings 1: 37-41.

Spender, John-Christopher (1996): Organizational knowledge, learning and memory: Three concepts in search of a theory. Journal of Organizational Change Management 9 (1): 63-78.

26 Spender, John-Christopher (1998): Pluralist Epistemology and the KnowledgeBased Theory of the Firm. Organization 5 (2): 233-256.

Tang, Tingan, Zhenyu Wu, Kimmo Karhu, Matti Hämäläinen in Yang Ji (2012): Internationally distributed living labs and digital ecosystems for fostering local innovations in everyday life. Journal of Emerging Technologies in Web Intelligence 4 (1): 106-115.

Treviño, A. Javier (2013): On the Facilitating Actions of Service Sociology. Journal of Applied Social Science 7 (1): 95-109.

Van der Have, Robert P. in Luis Rubalcaba (2016): Social innovation research: An emerging area of innovation studies? Research Policy 45 (9): 1923-1935.

Vujovič, Ana (2015): Evropski forum o socialnih inovacijah in aktivnem staranju. Kakovostna starost 18 (3): 71-72.

Young, H. Peyton (2011): The dynamics of social innovation. Proceedings of the National Academy of Sciences 108 (4): 21285-21291.

Žiberna, Tamara Rape (2017): Konceptualizacija inovacij v socialnem delu. Socialno delo 56 (2): 111-127.

VIRI

Bureau of European Policy Advisers (2010): Empowering people, driving change: Social innovation in the European Union. Bruselj: Evropska komisija.

European Commission (2014): Social Innovation - A decade of Changes. Dostopno prek https://espas.secure.europarl.europa.eu/orbis/document/social-innovation-decade-changes, 20. 6.2019. 
European Commission (2019): What is HORIZON 2020: Responsible Research \& Inniovation. Dostopno prek https://ec.europa.eu/programmes/horizon2020/ en/h2020-section/responsible-research-innovation, 15. 5. 2020.

European Network of Living Labs (2019a): What are Living Labs. Dostopno prek https://enoll.org/about-us/what-are-living-labs/, 15. 5. 2020.

European Network of Living Labs (2019b): AIPA - Ageing in Place Aalst. Dostopno prek https://enoll.org/network/living-labs/?livinglab=aipa-ageing-in-place-aalst \#description, 15. 5. 2020.

GOV.SI (2017): Slovenska strategija pametne specializacije S4. Dostopno prek https://www.gov.si/assets/vladne-sluzbe/SVRK/S4-Slovenska-strategijapametne-specializacije/S4_strategija_V_Dec17.pdf, 15.5.2020.

GOV.SI (2019): Informacija o izvajanju slovenske strategije pametne specializacije za obdobje 2016-2018. Dostopno prek https://www.gov.si/assets/vladnesluzbe/SVRK/S4-Slovenska-strategija-pametne-specializacije/Informacija-oizvajanju-S4-2016-2018.pdf, 15. 5. 2020.

Wenger, Etienne (2011): Communities of practice: https://scholarsbank.uoregon. edu/xmlui/handle/1794/11736, 10. 6. 2020. 